\title{
Antifeedants and Feeding Stimulants in Bark Extracts of Ten Woody Non-host Species of the Pine Weevil, Hylobius abietis
}

\author{
Carina Eriksson • Per E. Månsson • Kristina Sjödin • \\ Fredrik Schlyter
}

Received: 25 November 2007 /Revised: 8 July 2008 / Accepted: 18 July 2008 / Published online: 22 August 2008

(C) Springer Science + Business Media, LLC 2008

\begin{abstract}
Bark of ten woody species, known to be rejected as a food source by the pine weevil, Hylobius abietis, were sequentially extracted by a Soxhlet apparatus with pentane followed by methanol. Species were alder (Alnus glutinosa), aspen (Populus tremula), beech (Fagus sylvatica), guelder rose (Viburnum opulus), holly (Ilex aquifolium), horse chestnut (Aesculus hippocastanum), lilac (Syringa vulgaris), spindle tree (Evonymus europaeus), walnut (Juglans regia), and yew (Taxus baccata). Bark of each species was collected in southern Scandinavia during the summer. Resulting extracts were tested for antifeedant activity against the pine weevil by a micro-feeding choice assay. At a dose corresponding to that in the bark, methanol extracts from Aesculus, Taxus, Ilex, and Populus were antifeedant active, while pentane extracts of Aesculus, Fagus, Syringa, and Viburnum were stimulatory. Four known antifeedants against H. abietis, the straight-chained carboxylic acids, hexanoic and nonanoic acid (C6 and C9), carvone, and carvacrol were identified by gas chromatography (GC)-mass spectrometry (MS) in several extracts. The major constituents were identified and tested for feeding deterrence. The aromatic
\end{abstract}

C. Eriksson $(\bowtie) \cdot$ K. Sjödin

Department of Natural Sciences, Mid Sweden University,

SE-851 70 Sundsvall, Sweden

e-mail: carina.eriksson@expancel.com

\section{P. E. Månsson • F. Schlyter}

Chemical Ecology, Department of Crop Protection Biology,

Swedish University of Agricultural Sciences,

P.O. Box 102, SE-230 53 Alnarp, Sweden

Present Address:

P. E. Månsson

Tunworth Crescent,

42 Bramley House,

SW15 4 PH London, UK compounds benzyl alcohol and 2-phenylethanol are new non-host plant-derived feeding deterrents for the pine weevil. Additionally, two feeding stimulants, $\beta$-sitosterol and 5(hydroxymethyl)-2-furaldehyde, were identified. One active methanol extract of Aesculus bark was sequentially fractionated by liquid chromatography, and major compounds were tentatively identified as branched alcohols and esters of hexanoic acid. Five commercially available hexanoate esters and two commercially available branched alcohols were identified as new active antifeedants. Both stimulatory and inhibiting compounds were found in the same extracts and co-eluted in the same or adjacent fractions. The mix of semiochemicals of opposite activity in each extract or fraction could explain the stimulatory-, inhibitory-, or sometimes neutral activity. Generally, such co-occurrence confounds the isolation of antifeedants.

Keywords Phagostimulant - Carboxylic acid - Bark extract . Limonene · Carvone · Carvacrol · Eugenol · Benzyl alcohol · Benzoic acid · 2-Phenylethanol $\cdot \beta$-Sitosterol .

Hexanoate esters $\cdot$ Branched alcohols

\section{Introduction}

Maturation feeding by juvenile and adult imagoes of the pine weevil, Hylobius abietis L., on small transplanted conifer plants causes severe problems in reforestation on felled areas in Northern Europe (Långström and Day 2004). Currently, insecticides, such as pyrethroids, are used to protect newly planted seedlings. Pyrethroids are toxic not only to insects but also to aquatic organisms. Indeed, cypermethrin, presently approved in Sweden, is even more toxic than the recently banned permethrin (McLeese et al. 1980). Thus, it is desirable that the use of such toxic 
compounds be replaced by more environmentally friendly protection methods. One promising strategy is the application of plant-derived protective antifeedant compounds onto plants (Klepzig and Schlyter 1999; Bratt et al. 2001; Sibul et al. 2001; Thacker et al. 2003; Schlyter 2004).

The adult pine weevil accepts numerous non-host species for feeding but prefers Scots pine (Pinus sylvestris L.) over most woody species of the Scandinavian flora (Manlove et al. 1997; Månsson and Schlyter 2004). However, there are at least 11 woody species upon which the weevil will avoid feeding even in no-choice tests (Månsson and Schlyter 2004). These are alder (Alnus glutinosa (L.) Gaertner), aspen (Populus tremula L.), beech (Fagus sylvatica L.), guelder rose (Viburnum opulus L.), holly (Ilex aquifolium L.), horse chestnut (Aesculus hippocastanum L.), linden (Tilia cordata Mill.), lilac (Syringa vulgaris L.), spindle tree (Evonymus europaeus L.), walnut (Juglans regia L.), and yew (Taxus baccata L.). Our general hypothesis is that the avoidance of weevils feeding on these species is caused by antifeedants present in the bark. Thus, we investigated chemical compositions.

The bark of one species, linden (Tilia cordata), contains nonanoic acid, which is a potent antifeedant against the pine weevil (Månsson et al. 2005). Several analogues of nonanoic acid are also active antifeedants (Månsson et al. 2006). While reports of the occurrence of similar carboxylic acids in bark tissue are sparse, several have been found in other tissues from some of the 11 woody species (Nahrstedt et al. 1981; Buttery et al. 2000).

To determine if the bark of the ten species rejected by the weevil, except for Tilia, also contains antifeedants against H. abietis, their barks were extracted with non-polar and polar solvents, and the extracts were tested for activity. Tests were made with doses corresponding to those occurring naturally in bark. The content of known antifeedants in the extracts was determined by gas chromatography (GC)-mass spectrometry (MS). The major compounds identified in the extracts were tested for activity. Additionally, an antifeedant active methanol extract of horse chestnut was fractionated. Stimulatory and inhibitory compounds in the resulting fractions were identified and bio-assayed.

\section{Methods and Materials}

Bark Extraction Branches and shoots (5- to 30-mm diam) from the ten plants, Viburnum, Evonymus, Alnus, Juglans, Fagus, Aesculus, Taxus, Ilex, Populus, and Syringa, were collected during the summer in southern Sweden. Only young plant material (second-year shoots and branches) was used. Preparation and extraction of the bark were performed as previously described (Månsson 2005; Månsson et al. 2005). Prior to removal of bark from twigs, the total bark area was measured. Outer and inner bark were cut or scraped off the stem, immersed in liquid nitrogen, and ground in a mortar. Pulverized bark was extracted first in a Soxhlet apparatus (Furniss et al. 1989) with boiling pentane $(300 \mathrm{ml})$. After $2 \mathrm{~h}$, the solvent was changed to methanol $(\mathrm{MeOH} ; 300 \mathrm{ml})$, and the extraction continued for another $2 \mathrm{~h}$. The resulting extracts (one non-polar pentane and one polar $\mathrm{MeOH}$ for each species) were filtered through silica gel ( $\sim 1 \mathrm{~g})$, which was, in both cases, washed with $\mathrm{MeOH}$ $(\sim 5 \mathrm{ml})$ prior to being concentrated in a rotary evaporator.

Bioassays Adult $H$. abietis were collected and stored with a food source (pine twigs) and water in buckets kept in darkness at $8-10^{\circ} \mathrm{C}$ as described earlier (Klepzig and Schlyter 1999; Schlyter et al. 2004a). Before starting an assay, buckets were moved into a growth chamber in which the parameters were set to those found in the field at the time of the weevil collection $\left[24^{\circ} \mathrm{C}, 75 \% \mathrm{RH}\right.$, and a photo period of 20:4 h (L/D)]. Twigs were removed 6 days before the start of a micro-feeding assay ( $24 \mathrm{~h}$ before a twig test), and water was removed 1 day before (Schlyter et al. 2004a).

The micro-feeding assay is a choice test that uses two plates, cut from thin-layer cellulose chromatography Al plates $(5 \times 5 \mathrm{~mm}$, Merck \#1.0552), that were placed in Petri dishes (9-cm diam) and were allowed to run for $4 \mathrm{~h}$. The method is described in detail previously (Schlyter et al. 2004a). Concentrated extracts were diluted with either pentane or methanol. The amount of solvent was determined on the basis of the total bark area extracted. Thus, if the bark area corresponded to, for example, 200 thin-layer chromatography (TLC) plates, each of $25 \mathrm{~mm}^{2}$, solvent was added until a volume of $200 \times 10 \mu \mathrm{l}(2 \times 5 \mu \mathrm{l})$ was reached. Then, $2 \times 5 \mu \mathrm{l}$ of the diluted extract were applied to the TLC test plate (Månsson et al. 2005). Hence, the dose (amount/area unit) of any compound on the test plate equaled that in the bark, assuming no loss during extraction and a bark thickness equal to the cellulose layer. These assumptions are not met exactly, but the deviations from the two assumptions will be of opposite directions and will partly cancel out.

Synthetic compounds tested (Tables 1, 2, and 3) were applied in $1.5-\mu \mathrm{l}$ aliquots in a $10 \% \mathrm{MeOH}$ solution. After solvent evaporation from both the treatment and solvent blank plates, $5 \mu \mathrm{l}$ of $1 \mathrm{M}$ sucrose in water were added as a feeding stimulant to both (Schlyter et al. 2004a).

Twig no-choice tests were performed on $12-\mathrm{mm}$ long $P$. sylvestris twig sections of approximately equal diameter (6- to $10-\mathrm{mm}$ diam), which were dipped in solutions of the compound to be tested. The method is described in detail (Klepzig and Schlyter 1999; Schlyter et al. 2004a).

The Anti-Feedant Index, AFI, was the variable used to quantify results from the assays (Schlyter et al. 2004a). The 
Table 1 Content of known antifeedants identified in pentane and methanol extracts of ten woody non-host species and their activity against Hylobius abietis

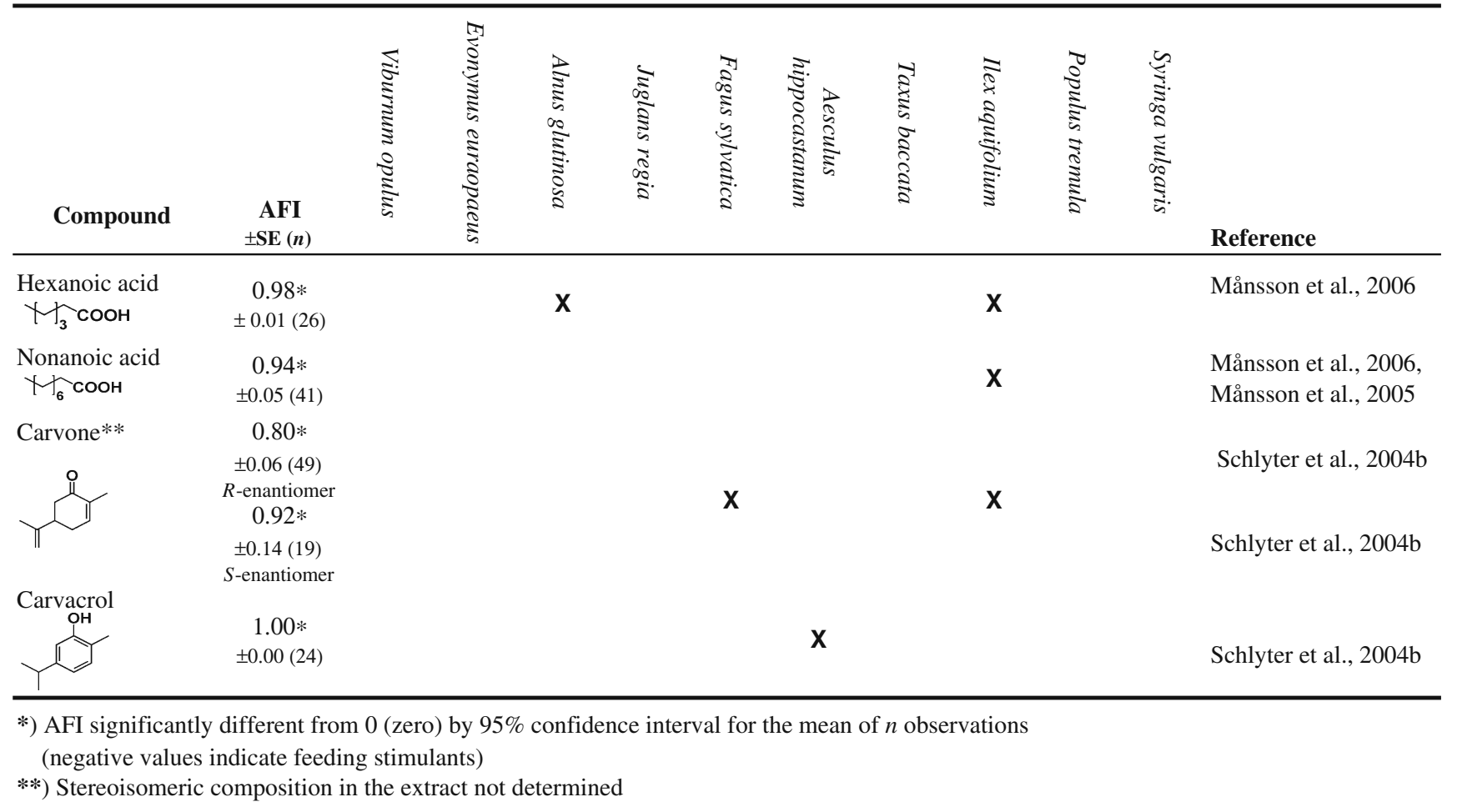

area eaten on the control plate $(C)$ is related to the area eaten on the test plate $(T)$ : AFI $=(C-T) /(C+T)$. Negative values $(<0)$ indicate a feeding stimulation, while a value of 1.00 corresponds to total feeding inhibition. A value of 0.50 indicates a half effect and 0 no effect. AFI values are presented as their arithmetic means \pm SE (standard error of the mean), and activity is considered significant if the $95 \%$ confidence interval for the mean $(95 \% \mathrm{CI})$ does not overlap zero.

The AFI obtained from the dose-response test with $10 \%$, $1 \%$, and $0.1 \%$ solutions in the micro-assays provides an $\mathrm{ED}_{50}$ value. The $\mathrm{ED}_{50}$ is the effective dose (expressed as concentration in percent of the treatment solution) that is needed for achieving a $50 \%$ feeding deterrent effect (i.e., the dose required to get an $\mathrm{AFI}=0.5$ ).

Fractionation of Aesculus Methanol Extract All solvents were distilled prior to use. The $\mathrm{MeOH}$ extract from Aesculus bark (M1) was fractionated by reverse phase LC by using octadecyl functionalized silica gel (12 g, SigmaAldrich Sweden AB) in a flash column (10 mm i.d.). The gradient used was one-column volume $(10 \mathrm{ml})$ of $\mathrm{MeOH}$ followed by $10 \mathrm{ml}$ of $50 \% \mathrm{CH}_{2} \mathrm{Cl}_{2}$ in $\mathrm{MeOH}, 10 \mathrm{ml}$ $\mathrm{CH}_{2} \mathrm{Cl}_{2}, 10 \mathrm{ml} 50 \%$ pentane in $\mathrm{CH}_{2} \mathrm{Cl}_{2}$, and finally, $20 \mathrm{ml}$ of pentane. In total, 14 fractions, each of $\approx 4 \mathrm{ml}$, were collected. The fractions containing similar compounds (as judged by TLC) were pooled. Each of the resulting eight fractions (M1:1-8) were concentrated to $1 \mathrm{ml}$ by flushing a gentle stream of argon over the solution, and they were subsequently tested in the micro-feeding assay.

One fraction (M1:3) had antifeedant activity and was further fractionated on silica gel 60 ( $6.5 \mathrm{~g}$, Fluka) on a flash column $(10 \mathrm{~mm}$ i.d.). The elution gradient was $20 \mathrm{ml}$ of $\mathrm{CH}_{2} \mathrm{Cl}_{2}$ followed by $10 \mathrm{ml}$ of $10 \% \mathrm{MeOH}$ in $\mathrm{CH}_{2} \mathrm{Cl}_{2}$, $10 \mathrm{ml} 20 \% \mathrm{MeOH}$ in $\mathrm{CH}_{2} \mathrm{Cl}_{2}, 10 \mathrm{ml} 50 \% \mathrm{MeOH}$ in

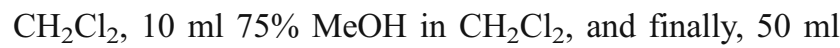
$\mathrm{MeOH}$. In total, 30 fractions, each of $\approx 4 \mathrm{ml}$, were collected. By merging fractions of similar chemical content as determined by TLC, the number of fractions was reduced to nine (M1:3:1-9), concentrated, and tested in the microfeeding assay.

Chemical Analysis Bark extracts were analyzed by GC-MS on a Varian 3800 GC instrument with a CP-sil 5CB lowbleed column (Varian, $30 \mathrm{~m} \times 0.25 \mathrm{~mm}$ i.d., $0.25 \mu \mathrm{m}$ film thickness), in series with a Saturn 2000 MS, ion trap detector, EI mode. All compounds in Tables 1 and 2 were identified by comparing their retention times and mass spectra with those of the reference compounds co-injected on the same instrument under the same analytical conditions.

Chemical Compounds ( $Z$ )-3-Hexenyl hexanoate was purchased from Bedoukian Research, $\beta$-sitosterol was purchased from Fluka. Tetradecyl hexanoate was synthesized 
Table 2 Identified and tested compounds in pentane and methanol extracts of the ten woody non-host species and their activity against Hylobius abietis

\begin{tabular}{|c|c|c|c|c|c|c|c|c|c|c|c|}
\hline Compound & $\begin{array}{c}\text { AFI } \\
\pm \text { SE }(n)\end{array}$ & 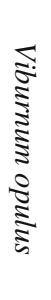 & 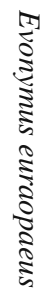 & 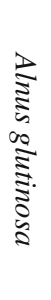 & 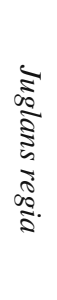 & 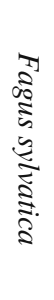 & 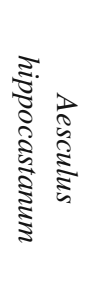 & 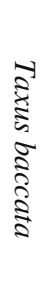 & 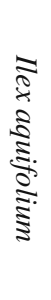 & 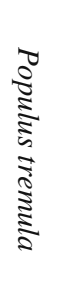 & 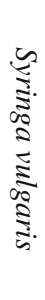 \\
\hline$\underbrace{\text { Hexadecanoic acid }}_{H_{13}}$ & $\begin{array}{c}0.16 \\
\pm 0.09(28)\end{array}$ & $\mathbf{x}$ & $\mathbf{X}$ & $\mathbf{X}$ & $\mathbf{X}$ & $\mathbf{X}$ & $\mathbf{X}$ & $\mathbf{X}$ & $X$ & $\mathbf{X}$ & $\mathbf{X}$ \\
\hline Linoleic acid & $\begin{array}{c}-0.15 \\
\pm 0.10(29)\end{array}$ & $\mathbf{x}$ & $X$ & $X$ & $X$ & $\mathbf{X}$ & $\mathbf{X}$ & $\mathbf{X}$ & $\mathbf{X}$ & $\mathbf{X}$ & $\mathbf{x}$ \\
\hline$\underbrace{\text { Linolenic acid }}$ & $\begin{array}{c}-0.09 \\
\pm 0.08(36)\end{array}$ & & & & & & & & & $\mathbf{X}$ & \\
\hline Limonene** & $\begin{array}{c}0.05 \\
\pm 0.13(19)\end{array}$ & & $\mathbf{X}$ & & & & $\mathbf{X}$ & & $\mathbf{X}$ & & \\
\hline Eugenol & $\begin{array}{c}1.00 * \\
\pm 0.00(14)\end{array}$ & $\mathbf{x}$ & & & & $\mathbf{X}$ & $\mathbf{X}$ & $\mathbf{X}$ & & & \\
\hline Benzyl alcohol & $\begin{array}{c}0.59 * \\
\pm 0.17(17)\end{array}$ & & & & $X$ & & & & $\mathbf{X}$ & $\mathbf{x}$ & \\
\hline$\underset{\text { CHO }}{\text { Vanillin }}$ & $\begin{array}{c}0.01 \\
\pm 0.25(14)\end{array}$ & & $X$ & $\mathbf{X}$ & & $\mathbf{X}$ & & $\mathbf{X}$ & $\mathbf{X}$ & & \\
\hline Benzoic acid & $\begin{array}{c}-0.18 \\
\pm 0.13(19)\end{array}$ & & $\mathbf{X}$ & & $\mathbf{X}$ & $\mathbf{X}$ & $\mathbf{X}$ & $\mathbf{X}$ & $\mathbf{X}$ & $\mathbf{x}$ & $\mathbf{X}$ \\
\hline Cinnamic acid & $\begin{array}{c}-0.02 \\
\pm 0.11(28)\end{array}$ & & & & & & & $x$ & & $x$ & \\
\hline 2-Phenylethanol & $\begin{array}{c}1.00 * \\
\pm 0.01(19)\end{array}$ & & & & & & & & $\mathbf{X}$ & $\mathbf{X}$ & \\
\hline Benzaldehyde & $\begin{array}{c}-0.16 \\
\pm 0.12(20)\end{array}$ & & $\mathbf{x}$ & & & & $\mathbf{X}$ & $\mathrm{x}$ & $\mathbf{x}$ & $\mathbf{x}$ & $x$ \\
\hline $\begin{array}{l}\text { 2-Furaldehyde } \\
0-\text { CHO }\end{array}$ & $\begin{array}{c}-0.16 \\
\pm 0.13(24)\end{array}$ & $\mathbf{x}$ & $\mathbf{X}$ & $\mathbf{x}$ & $X$ & $\mathbf{X}$ & $\mathbf{X}$ & & & $\mathbf{X}$ & $\mathbf{x}$ \\
\hline $\begin{array}{l}\text { 5-(Hydroxymethyl)-2- } \\
\text { furaldehyde }\end{array}$ & $\begin{array}{c}-0.32 * \\
\pm 0.13(19)\end{array}$ & & & & $\mathbf{X}$ & & $\mathbf{X}$ & & & $\mathbf{x}$ & $\mathbf{x}$ \\
\hline & $\begin{array}{c}-0.27 * \\
\pm 0.09 \text { (38) }\end{array}$ & $\mathbf{x}$ & $\mathbf{X}$ & $\mathbf{x}$ & $\mathbf{X}$ & $\mathbf{X}$ & $\mathbf{X}$ & $\mathbf{X}$ & & $\mathbf{X}$ & $\mathbf{X}$ \\
\hline
\end{tabular}

*) AFI significantly different from 0 (zero) by $95 \%$ confidence interval for the mean of $n$ observations (negative values indicate feeding stimulants)

**) Stereoisomeric composition in the extract not determined 
Table 3 The antifeedant activity in Hylobius abietis of hexanoate esters and branched aliphatic alcohols, lead compounds tentatively identified from horse chestnut extracts

${ }^{a}$ AFI significantly different from 0 (zero) by $95 \%$ confidence interval for the mean of $n$ observations

\begin{tabular}{|c|c|c|c|}
\hline Compound & $\mathrm{AFI} \pm \mathrm{SE}(n)$ & $\mathrm{ED}_{50}(\%) \pm \mathrm{SE}(n)$ & $\mathrm{AFI}$ twig $\pm \mathrm{SE}(n)$ \\
\hline (Z)-3-Hexenyl hexanoate & $0.99^{\mathrm{a}} \pm 0.01(10)$ & & \\
\hline Hexyl hexanoate & $0.87^{\mathrm{a}} \pm 0.10$ & & \\
\hline 2-Methylbutyl hexanoate & $0.86^{\mathrm{a}} \pm 0.07$ & & \\
\hline 3-Methylbutyl hexanoate & $0.88^{\mathrm{a}} \pm 0.06$ & & \\
\hline iso-Butyl hexanoate & $0.83^{\mathrm{a}} \pm 0.10$ & & \\
\hline Tetradecyl hexanoate & $0.32 \pm 0.16(19)$ & & \\
\hline 2-Butyl-1-octanol & $0.86^{\mathrm{a}} \pm 0.10$ & $0.76 \pm 0.59(2)$ & $0.21^{\mathrm{a}} \pm 0.07(20)$ \\
\hline 2-Ethyl-1-hexanol & $0.93^{\mathrm{a}} \pm 0.08$ & & $0.11 \pm 0.16(10)$ \\
\hline 2-Hexyl-1-decanol & $0.17 \pm 0.09$ & & $0.24^{\mathrm{a}} \pm 0.10(10)$ \\
\hline
\end{tabular}

from hexanoic acid and tetradecanol; spectral data $\left({ }^{1} \mathrm{H},{ }^{13} \mathrm{C}\right.$ NMR, and MS) were satisfactory. All other chemical compounds in Tables 1, 2, and 3 were purchased from Sigma-Aldrich Sweden AB.

\section{Results}

Twenty extracts (one pentane and one methanol of each species) of Alnus, Populus, Fagus, Ilex, Aesculus, Viburnum, Syringa, Evonymus, Juglans, and Taxus were tested twice in the micro-assay. In the first run, the highest antifeedant activity was found for the methanol extract of Aesculus $(N=7)$. Combining the results from both test runs, the methanol extracts of Populus, Ilex, Aesculus, and Taxus were all active in inhibiting feeding (AFI 95\% CI were all $>0$, Fig. 1). None of the pentane extracts displayed any antifeedant activity in these species. In contrast, the pentane extracts of Fagus, Viburnum, Aesculus, and Syringa significantly stimulated feeding (AFI 95\% CI were all <0, Fig. 1).

The content of known antifeedants, such as straightchained aliphatic carboxylic acids in the range C6-C9 (Månsson et al. 2006), carvone, and carvacrol (Schlyter et al. 2004b) in the 20 extracts was determined by GC-MS (Table 1). Among known active carboxylic acids, the feeding deterrents hexanoic acid (in the pentane extract of Ilex and Alnus) and nonanoic acid (in the pentane extract of Ilex) were detected. The known pine weevil antifeedants carvone and carvacrol were found in the pentane extracts of Fagus and Ilex, and in the methanol extract of Aesculus, respectively (stereoisomeric composition of carvone in the extracts was not determined; however, both enantiomers are active antifeedants, Table 1).

Additionally, major compounds in the extracts were identified, and those available were tested in the microassay (Table 2). The antifeedant active methanol extracts of Aesculus, Taxus, and Populus contained one or more of the deterrent, aromatic compounds carvacrol, eugenol, or benzyl alcohol (Tables 1 and 2). To our knowledge, the latter, together with 2-phenylethanol that was found in the pentane extracts of Ilex and Populus, have not been reported previously as feeding deterrents for the pine weevil. Two aldehydes, 2-furaldehyde (furfural) and 5-(hydroxymethyl)-2furaldehyde (5-hydroxymethylfurfural), were found in some extracts with antifeedant activity. While no activity was found for 2-furaldehyde, 5-(hydroxymethyl)-2-furaldehyde stimulated feeding (AFI significantly $<0$ ). Another feeding stimulant, $\beta$-sitosterol, was detected in the majority of the extracts (Table 2). Hexadecanoic acid, which was identified in almost all extracts (both pentane and methanol), did not exhibit any antifeedant activity (Table 2). Two other longchain carboxylic acids, linoleic acid that was found in several pentane and methanol extracts and linolenic acid present in the pentane extract of Populus, seemed to

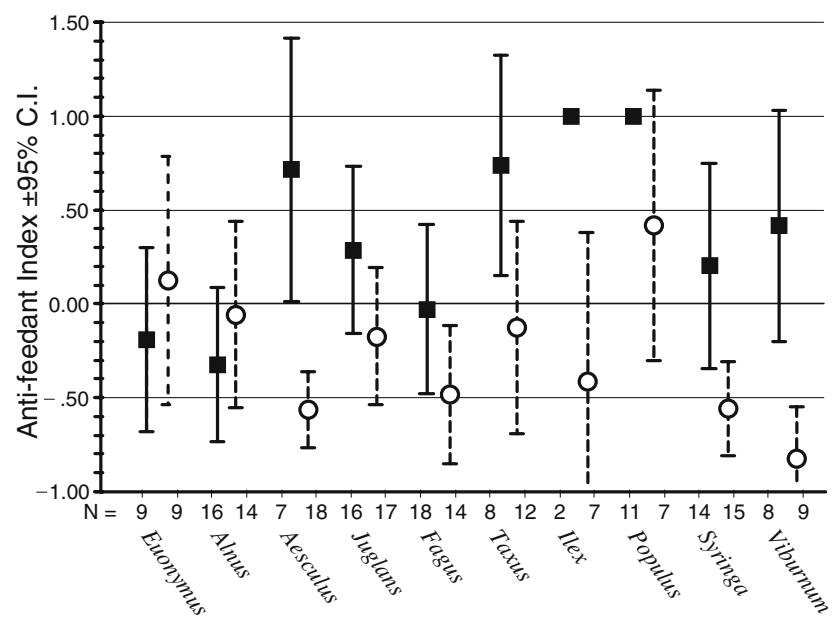

Fig. 1 Antifeedant index (AFI) of pentane (lines with open circles) and methanol (lines with filled squares) extracts in micro-feeding assay choice test of ten woody non-hosts. Plants extracted included spindle tree (Evonymus europaeus), alder (Alnus glutinosa), horse chestnut (Aesculus hippocastanum), walnut (Juglans regia), beech (Fagus sylvatica), yew (Taxus baccata), holly (Ilex aquifolium), aspen (Populus tremula), lilac (Syringa vulgaris), and guelder rose (Viburnum opulus). $N$ on the $x$-axis is the number of data points (individual beetles in Petri dishes) where an AFI could be calculated, i.e., when feeding occurred on at least one of the paired plates in the dish. AFI relates the area eaten on the control plate $(C)$ to that on the test plate $(T): A F I=(C-T) /(C+T)$ and ranges from -1 to +1 
stimulate feeding but not significantly so (both AFI $<0$ ). Five common plant constituents, limonene, vanillin, benzoic acid, cinnamic acid, and benzaldehyde, were identified in some extracts but showed no effect on the weevil (AFI $\sim 0$, Table 2).

Since Aesculus was the only species that yielded both inhibitory (methanol) and stimulatory (pentane) extracts and was active in the first micro-feeding test, the active methanol extract (M1) was chosen for fractionation. Reverse-phase liquid chromatography resulted in eight fractions, of which several (M1:4 to M1:8) were phagostimulatory. Only fraction M1:3 displayed significant antifeedant activity (Fig. 2). However, when the eight fractions were combined, the activity was lost (M1 sum, Fig. 2). Fractions M1:2 (slightly antifeedant) and M1:3 (active antifeedant) contained similar patterns of compounds with one exception; fraction M1:2 contained a large amount of the feeding stimulant 5-(hydroxymethyl)-2-furaldehyde, while M1:3 did not.

A second chromathographic separation of the antifeedant active fraction M1:3 on straight phase silica gel resulted in nine fractions of which the last (M1:3:9) exhibited the highest activity (Fig. 3). In contrast, several fractions had $\mathrm{AFI}<0$, and fraction $\mathrm{M} 1: 3: 5$ strongly $(\mathrm{AFI}<<0)$ and significantly stimulated weevil feeding on treated plates (Fig. 3). Two compounds were common in fractions M1:3:8 and M1:3:9, and their mass spectra showed they were aliphatic esters of hexanoic acid. The mass spectra and retention times of these compounds were compared with

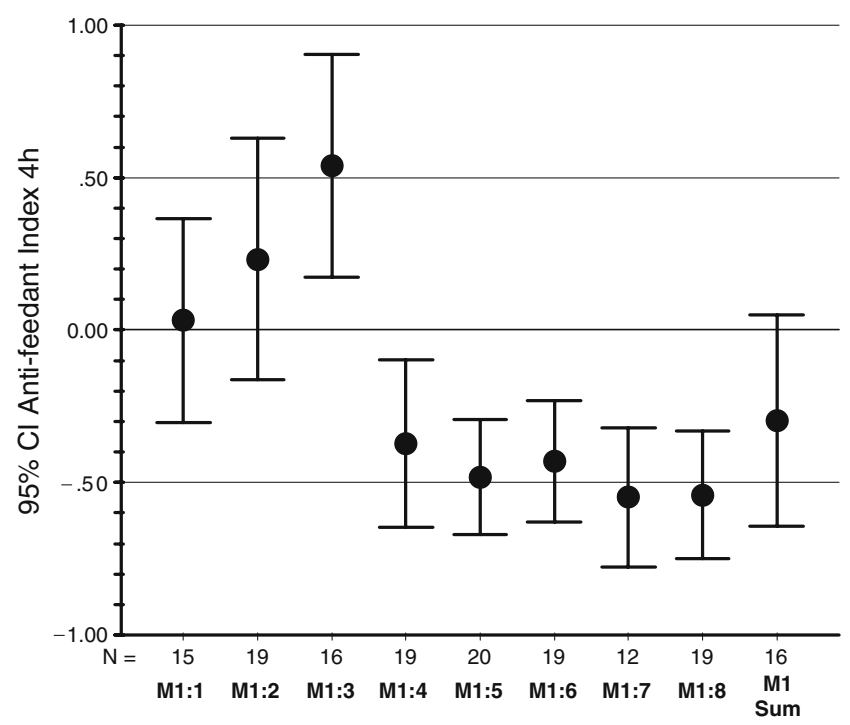

Fig. 2 Feeding activity of fractions of the first Aesculus methanol extract in micro-feeding assay no-choice tests. $N$ on the $x$-axis is the number of data points (individual beetles in Petri dishes) where an AFI could be calculated, i.e., when feeding occurred on at least one of the paired plates in the dish. M1:sum joined extract from pooling all fractions

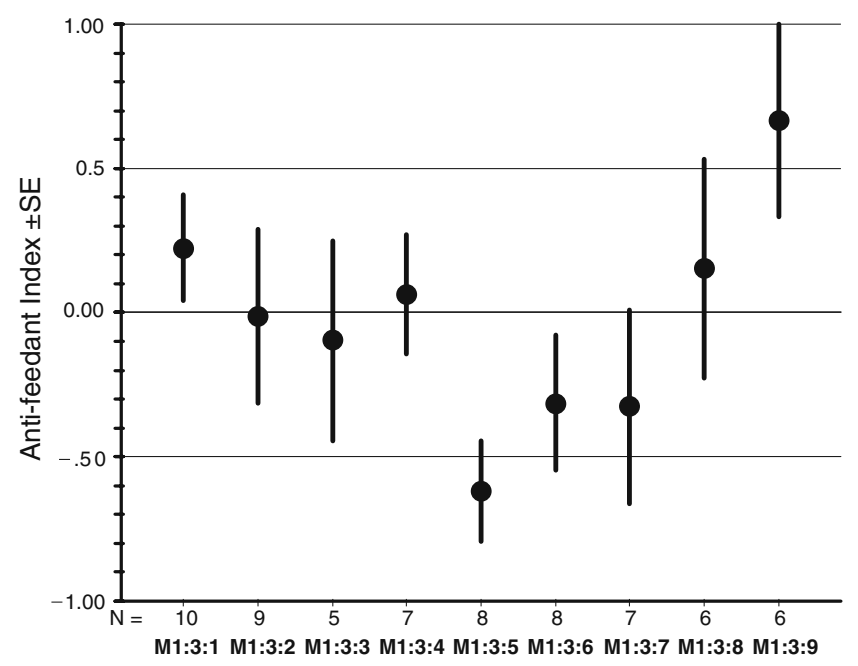

Fig. 3 Feeding activity of the sub-fractions of fraction M1:3 from the first Aesculus methanol extract in micro-feeding assay no-choice tests. $N$ on the $x$-axis is the number of data points (individual beetles in Petri dishes) where an AFI could be calculated, i.e., when feeding occurred on at least one of the paired plates in the dish

those of reference samples of some esters of that type (tetradecyl-, tridecyl-, dodecyl-, and hexyl hexanoate), but neither the mass spectra nor the retention times were identical with any of the reference esters. Interestingly, when six available esters of this type were tested in the micro-feeding assay, five out of six were active antifeedants with AFIs $>0.80$ (Table 3). The most active was (Z)-3hexenyl hexanoate, followed by hexyl hexanoate, 2methylbutyl hexanoate, 3-methylbutyl hexanoate, and iso-butyl hexanoate. The heavier tetradecyl hexanoate was not active.

The mass spectra of other major components in the slightly antifeedant active fraction M1:3:8 indicated they were branched aliphatic alcohols. Three alcohols of that type were available, namely 2-butyl-1-octanol, 2-ethyl-1hexanol, and 2-hexyl-1-decanol, but their retention times were not identical with those in the extracts. In the microfeeding assay at a $10 \%$ dose, they displayed varying antifeedant activities (Table 3): high activity for 2-butyl-1octanol and 2-ethyl-1-hexanol but low activity for 2-hexyl1-decanol. The $\mathrm{ED}_{50}$ for 2-butyl-1-octanol in the choice micro-assay was as low as $0.8 \%( \pm 0.6 N=2)$, indicating high activity. When tested on twigs, less activity than in the micro-feeding assay was obtained for 2-butyl-1-octanol and 2-ethyl-1-hexanol, while 2-hexyl-1-decanol showed the same low activity as in the micro-feeding assay.

\section{Discussion}

Eleven new active compounds were found during this study. Two of these, $\beta$-sitosterol and 5-(hydroxymethyl)-2- 
furaldehyde (5-hydroxymethyl furfural), are the first reported feeding stimulants from non-host plants of the pine weevil. Another two, benzyl alcohol and 2-phenylethanol, were new antifeedants that were identified in several non-host plants. Aliphatic esters of hexanoic acid and branched aliphatic alcohols were tentatively identified in active extracts. Nine compounds belonging to either of these classes of compounds were tested, and seven were antifeedants.

Apart from the 11 new active compounds and the four known antifeedants identified in non-host plants (Table 1), the contrasting activity of polar and nonpolar extracts is a striking finding. Activities of extracts are related to the polarity of the solvent used for extraction (Fig. 1). Thus, only four out of ten plant barks furnished active inhibitory extracts (Populus, Ilex, Aesculus, and Taxus), and all of these were methanol extracts. In contrast, the pentane extracts of Fagus, Viburnum, Aesculus, and Syringa were strongly feeding stimulatory. Only the bark of one species, Aesculus, produced extracts that were both stimulatory (pentane) and inhibitory ( $\mathrm{MeOH})$.

We previously showed that some aliphatic carboxylic acids (in the range $\mathrm{C} 6-\mathrm{C} 10$ ) act as antifeedants against the pine weevil (Månsson et al. 2005, 2006). Of these, nonanoic acid was found in a dichloromethane/methanol bark extract of Tilia (Månsson 2005; Månsson et al. 2005). In addition, hexanoic, heptanoic, octanoic, and nonanoic acids have been found in Fagus wood (Guillén and Ibargoitia 1996). We found only hexanoic acid in the pentane bark extracts of Ilex and Alnus, and nonanoic acid in the pentane bark extract of Ilex (Table 1). Thus, the feeding avoidance of $H$. abietis on the ten woody species investigated in this work is not fully explained by the presence of these carboxylic acids, as it was for linden (Månsson et al. 2005, 2006).

Fractionation of the Aesculus methanol extracts led to the discovery of two new groups of pine weevil antifeedants, i.e., esters of hexanoic acid and branched alcohols. Additionally, the aromatic compounds benzyl alcohol and 2-phenylethanol were identified as new antifeedants. Eugenol had earlier been found in a polar extract of the feces of $H$. abietis females. Similar to our results, the compound exhibited antifeedant activity against the weevil when tested in a feeding bioassay (Borg-Karlson et al. 2006). In accordance with the decreased antifeedant activity found for carboxylic acids with chains longer than C10 (Månsson et al. 2006), no antifeedant activity was found for hexadecanoic-, linoleic-, or linolenic acids that were present in almost all extracts (Table 1).

The heteroaromatic aldehyde 5-(hydroxymethyl)-2furaldehyde showed feeding stimulating properties. Previously, 5-(hydroxymethyl)-2-furaldehyde was reported as a constituent of the essential oil and head space extract of
Aesculus flowers (Buchbauer et al. 1994). However, both 5-(hydroxymethyl)-2-furaldehyde and 2-furaldehyde, which was also found in some extracts, could be artifacts formed by carbohydrate dehydration (Kallury et al. 1986; Antal Jr. et al. 1990), either during the extraction procedure or in the injector of the GC.

In contrast to the high feeding-deterrent activity found for some methoxy-substituted benzaldehyde derivatives (Eriksson 2006), benzaldehyde itself showed no antifeedant activity. However, the inactivity of cinnamic acid and benzoic acid was not surprising since earlier studies have shown that methoxy-substituted benzoic- and cinnamicacid derivatives are less active antifeedants than the corresponding aldehydes (Eriksson 2006) or methyl esters (Unelius et al. 2006).

All extracted species, except holly, contained $\beta$-sitosterol, which strongly stimulated feeding of $H$. abietis. This compound has been identified as a feeding stimulant for the obscure root weevil, Sciopithes obscurus Horn (Doss et al. 1982), an effect that was synergistically enhanced by adding sucrose (Shanks and Doss 1987). In our tests of $\beta$ sitosterol, sucrose was always added to the test plate.

Most extracts contained a complex mixture of antifeedant and feeding stimulatory compounds. Whether the final outcome of an extract was a feeding deterrent or a stimulatory effect was dependent on the mixture of compounds therein and on their concentrations. The feeding stimulant $\beta$-sitosterol, occurring in almost all extracts, was a minor constituent in the antifeedant active extracts, whereas in the feeding stimulatory and inactive extracts, it was a major constituent. Hence, the deterrent activity of the extracts appears to be partially dependent on the efficiency by which $\beta$-sitosterol is removed during the non-polar pentane extraction. The concentration dependence was exemplified by the fact that when the eight fractions of the active methanol extract of Aesculus were combined, deterrent activity was lost. Probably, this can be ascribed to the fact that the concentrations of the specific deterrents became too low relative to that of $\beta$-sitosterol.

Even after extensive fractionation of extracts, the difficulty of identifying antifeedants in the presence of feeding stimulating compounds remains. After fractionation of the first methanol extract of Aesculus, fractions M1:2 and M1:3 were found to have a similar composition. However, only fraction M1:3 (Fig. 2) showed feeding deterrent activity. This is possibly due to the absence of the feeding stimulant, 5-(hydroxymethyl)-2-furaldehyde, which was detected only in the less active fraction 2 (M1:2, Fig. 2).

In conclusion, eleven new active compounds were found in this study. Two of these, $\beta$-sitosterol and 5(hydroxymethyl)-2-furaldehyde, are the first reported feeding stimulants for the pine weevil, while another two compounds, benzyl alcohol and 2-phenylethanol, were 
found to be new antifeedants identified from several nonhosts of the weevil. Seven compounds belonging to either of the two classes of aliphatic esters of hexanoic acid or branched aliphatic alcohols were found to be active antifeedants. In addition, four earlier known antifeedant compounds were identified from four non-host plants. Our work suggests that further active compounds in the bark of these woody species remain to be identified.

Acknowledgment Elisabeth Marling is acknowledged for technical assistance and Dr. Tessa Pocock for comments on the manuscript. We are also grateful for financial support to the research program "Pheromones and kairomones for control of pest insects" from Mistra, the cross-disciplinary grant "Formulation of semiochemicals for plant protection against forest pest insects" from Formas, and from EU, "Objective 1: the region of south forest counties."

\section{References}

ANTAL, J. M. Jr., MoK, W. S. L., and Richards, G. N. 1990. Mechanism of formation of 5-(hydroxymethyl)-2-furaldehyde from D-fructose and sucrose. Carbohydr. Res. 199:91-109.

Borg-Karlson, A.-K., Nordlander, G., Mudalige, A., NordenheM, H., and UNELIUS, C. 2006. Antifeedants in the feces of the pine weevil Hylobius abietis: identification and biological activity. J. Chem. Ecol. 32:943-957.

Bratt, K., Sunnerheim, K., Nordenhem, H., Nordlander, G., and LÅgSTRÖM, B. 2001. Pine weevil (Hylobius abietis) antifeedants from lodgepole pine (Pinus contorta). J. Chem. Ecol. 27:2253-2262.

Buchbauer, G., Jirovetz, L., Wasicky, M., and Nikiforov, A. 1994. Volatiles of common horsechestnut (Aesculus hippocastanum L.) (Hippocastanaceae) blossoms. J. Essent. Oil Res. 6:93-95.

Buttery, R. G., Light, D. M., NAM, Y., Merrill, G. B., and RoITMAN, J. N. 2000. Volatile components from green walnut husks. J. Agric. Food Chem. 48:2858-2861.

Doss, R. P., Luthi, R., Edelman, D. L., and HrutFiord, B. F. 1982. Sitosterol and quercetin 3-galactoside, obscure root weevil feeding stimulants from rhododendron. J. Agric. Food Chem. 30:1079-1082.

ERIKSSON, C. 2006. Isolation, synthesis and structure-activity relationships of antifeedants against the pine weevil, Hylobius abietis. Doctoral thesis, Chemical Science and Engineering, Royal Institute of Technology (KTH), Stockholm, 63 pp, ISBN: 91-7178-301-6.

Furniss, B. S., HANNAFord, A. J., SMith, P. W. G., and TATChell, A. R. 1989. Vogel's Textbook of Practical Organic Chemistry. Longman Scientific \& Technical, Essex.

GuILLÉN, M. D., and IBARGOITIA, M. L. 1996. Volatile components of aqueous liquid smokes from Vitis vinifera L. shoots and Fagus sylvatica L. wood. J. Sci. Food. Agric. 72:104-110.

Kallury, R. K. M. R., Ambidge, C., Tiwell, T. T., Boocock, D. G. B., AbGlevor, F. A., and Stewart, D. J. 1986. Rapid hydrothermolysis of cellulose and related carbohydrates. Carbohydr. Res. 158:253-261.

KLEPZIG, K. D., and SCHLYTER, F. 1999. Laboratory evaluation of plant derived antifeedants against European pine weevil, Hylobius abietis. J. Econ. Entomol. 92:644-650.
LÅngSTRÖM, B., and DAY, K. R. 2004. Damage, control and management of weevil pests, pp. 415-444, in F. Lieutier, K. R. Day, A. Battisti, J.-C. Gregoire, and F. Evans (eds.). Bark and Wood Boring Insects in Living Trees in Europe, A SynthesisKluwer, Dordrecht, The Netherlands.

Manlove, J. D., Styles, J., and Leather, S. R. 1997. Feeding of the adults of the large pine weevil, Hylobius abietis (Coleoptera: Curculionidae). Eur. J. Entomol. 94:153-156.

MÅnsson, P. E. 2005. Host selection and antifeedants in Hylobius abietis pine weevils. Doctoral thesis, Deparment of Crop Science, Swedish University of Agricultural Sciences (SLU), Alnarp, 90 pp. ISBN: 91-576-7015-3. http://diss-epsilon.slu.se/archive/ 00000759/01/per200516.pdf.

MÅnsSON, P. E., and SCHLYTER, F. 2004. Hylobius pine weevils adult host selection and antifeedants: feeding behaviour on host and non-host woody Scandinavian plants. Agric. Forest Entomol. 6:165-171.

MÅnsson, P. E., ERIKSSON, C., and SJÖDIN, K. 2005. Antifeedants against Hylobius abietis pine weevils: an active compound in extract from bark of Tilia cordata Linden. J.Chem. Ecol. 31:9891001.

MÅnsson, P. E., Schlyter, F., ERiksson, C., and SJöDin, K. 2006. Nonanoic acid, other alkanoic acids, and related compounds as antifeedants in Hylobius abietis pine weevils. Entomol. Exp. Appl. 121:191-201.

MCleEse, D. W., Metcalfe, C. D., and ZitKo, V. 1980. Lethality of permethrin, cypermethrin and fencalerate to salmon, lobster and shrimp. Bull. Environ. Contam. Toxicol. 25:950-955.

NAhrstedt, A., Vetter, U., and HAMmerschmidt, F. J. 1981. Knowledge on the steam distillate from the leaves of Juglans regia. Planta Med. 42:313-332.

SCHLYTER, F. 2004. Semiochemicals in the life of bark feeding weevils, pp. 351-364, in F. Lieutier, K. R. Day, A. Battisti, J.-C. Gregoire, and F. Evans (eds.). Bark and Wood Boring Insects in Living Trees in Europe, A SynthesisKluwer, Dordrecht, The Netherlands.

SChlyter, F., MARling, E., and LÖFQVist, J. 2004a. A new microassay for antifeedants in Hylobius pine weevils (Coleoptera). J. Pest Sci. 77:191-195.

Schlyter, F., Smitt, O., SJöDin, K., HöGBerG, H.-E., and LÖFQVIST, J. 2004b. Carvone and less volatile analogues as repellent and deterrent antifeedants against the pine weevil, Hylobius abietis. J. Appl. Entomol. 128:610-619.

SHANKS, C. H., and Doss, R. P. 1987. Feeding responses by adults of five species of weevils (Coleoptera: Curculionidae) to sucrose and sterols. Ann. Entomol. Soc. Am. 80:41-46.

SibUl, I., LuiK, A., and Voolma, K. 2001. Possibilities to influence maturation feeding of the large pine weevil, Hylobius abietis L., with plant extracts and neem preparations, pp. 112-119, in Practice oriented results on the use of plant extracts and pheromones in pest control: Proceedings of the International Workshop, 24-5 January, 2001, Tartu, Estonia.

Thacker, J. R. M., Bryan, W. J., Mcginley, C., Heritage, S., and STRANG, R. H. C. 2003. Field and laboratory studies on the effects of neem (Azadirachta indica) oil on the feeding activity of the large pine weevil (Hylobius abietis L.) and implications for pest control in commercial conifer plantations. Crop Prot. 22:753-760.

Unelius, C. R., Nordlander, G., Nordenhem, H., Hellovist, C., LEGRAND, S., and BORG-KARLSSON, A.-K. 2006. Structureactivity relationships of benzoic acid derivatives as antifeedants for the pine weevil, Hylobius abietis. J. Chem. Ecol. 32:21912203. 